\title{
Undergraduate Financial AID AND SubSEQUent Alumni Giving BeHAVIOR
}

by

Kelley Dugan, Charles H. Mullin, and John J. Siegfried

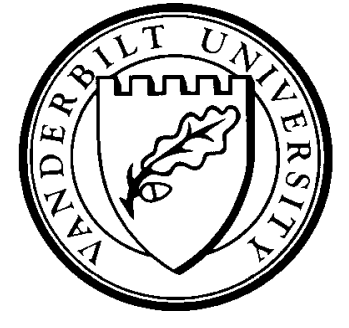

Working Paper No. 00-W40

October 2000

\author{
DEPARTMENT OF ECONOMICS \\ VANDERBILT UNIVERSITY \\ NASHVILLE, TN 37235
}

www.vanderbilt.edu/econ 


\title{
Undergraduate Financial Aid and Subsequent Alumni Giving Behavior
}

\author{
By \\ Kelly Dugan, Charles H. Mullin and John J. Siegfried* \\ Vanderbilt University
}

October 2000

\begin{abstract}
Data on 2,822 Vanderbilt University graduates are used to investigate alumni giving behavior during the eight years after graduation. A two stage model accounting for incidental truncation is used to first estimate the likelihood of making a contribution and second estimate the average gift size conditional on contributing. The type of financial aid received as an undergraduate appears to have a greater influence on subsequent alumni generosity than the amount received. Adding some scholarship to a loan-only package or eliminating all loans from a mixed loan-grant package increases the likelihood of a subsequent contribution. Increasing the total size of the package or altering the proportions of an already mixed package appears to be inconsequential for future donations. Students who receive small merit scholarships contribute more as alumni than students who receive either no merit scholarship or a large merit scholarship.
\end{abstract}

\footnotetext{
* Department of Economics, Vanderbilt University, Nashville, TN 37235. Email comments to: charles.mullin@vanderbilt.edu or siegfrij@ctrvax.vanderbilt.edu. Dugan is a 1999 graduate of the College of Arts \& Sciences. We thank both Greg Perfetto of the Provost's Office of Special Projects and Melanie Ford of the Office of Alumni and Development at Vanderbilt University for enormous help in assembling the data set used in this project.
} 


\section{Introduction}

Alumni provided over $\$ 5.5$ billion of voluntary support to colleges and universities in 1997-98 (Chronicle of Higher Education, 1999). Although this is less than five percent of higher education revenues, it represents critical revenues for certain institutions (Leslie and Ramey, 1998; Bande and Sundberg, 1993; Mulugetta, Nash and Murphy, 1999). In particular, America's research universities averaged more than $\$ 50$ million each in alumni contributions in 1997-98. In addition, alumni support is frequently less encumbered with restrictions than alternative revenues, and thus can be allocated to the highest valued incremental use.

In a seemingly unrelated event, the structure of financial aid recently underwent a dramatic change. Colleges and universities have begun to rely on financial aid policies as a strategy to maximize institutional revenues and to manage enrollment (McPherson and Schapiro, 1998). Merit aid has grown in importance relative to need-based aid, and the packaging of financial aid among grants, loans, employment opportunities, and self-help often is used to influence enrollment behavior as well as to provide access to post-secondary education. Additionally, the share of higher education costs shouldered by state governments has fallen in recent years (McPherson and Schapiro, tables 3.1 and 3.2). In response, federally and institutionally provided aid has risen, but virtually all of the rise has been in the form of loans rather than grants. Because most federal loan programs are administered through colleges and universities, loan repayment checks are written to an individual's alma mater.

In this paper, we attempt to link undergraduate financial aid decisions to alumni giving. In particular, we explore whether undergraduate college loan obligations affect alumni contributions. Do young alumni donate less to their alma mater if they have already "just sent them a check?" Alternatively, do young graduates view financial aid, including loans, as an enabling opportunity, without which they might not have been able to earn a degree at all? In short, do post-graduation loan obligations affect either the likelihood of giving by young alumni to their alma mater or the expected amount of their gift if they do contribute?

To explore these questions we estimate a two-stage decision process with incidental truncation. First, graduates decide whether or not to contribute. Second, conditional on contributing, they decide how much to give. In the first stage, we employ a probit model in which the dependent variable distinguishes alumni who donated to their alma mater at least once during 
the eight years immediately following their graduation from those who did not. Included among the explanatory variables are measures of both the existence and amount of various types of undergraduate financial aid. In the second stage, we regress the average annual gift size on the same undergraduate financial aid variables, correcting for the censored error distribution caused by the presence of non-givers in the sample.

Clotfelter (2000) also addresses directly the effects of financial aid on subsequent alumni donations. He finds no relationship between a binary variable representing the receipt of some need-based financial aid and alumni contributions for a cohort of 1951 freshmen at a sample of colleges and universities, but found a significant negative effect for the 1976 cohort at those same institutions. However, Clotfelter's study is limited by an absence of detail about the amount and composition of the need-based financial aid. The data used in this study, although with shortcomings of their own, are suited to address these latter problems. ${ }^{1}$

Our data consist of 2,822 full-time students who entered Vanderbilt University as freshmen in 1984, 1985, and 1986, and received their bachelors degrees from Vanderbilt between May 1988 and May 1990. Thus we include only college graduates who matriculated as freshmen; dropouts and transfer students are excluded. We have admissions, financial aid, student records, and contribution data for each of these individuals. During their first eight years after receiving their degree 1,538, or 54.5 percent of the graduates, donated to Vanderbilt at least once. Since Vanderbilt has very few students of non-traditional age, these donations effectively represent the cumulative giving history of individuals who are approximately 30 years old.

Our data have two major faults. First, they are from a single university, limiting the extent to which one can generalize our results. Second, there is no direct measure of either students' or their families' income or wealth. The potential effect of this latter point on the robustness of parameter estimates is discussed in detail later.

We hypothesize that graduates' willingness to donate to their alma mater depends primarily on satisfaction with their undergraduate experience, an important component of which

\footnotetext{
${ }^{1}$ Stutler and Calvario (1996) identify "satisfaction with financial aid services" as one of the nine categories of graduates' undergraduate experience that distinguish alumni donors from non-donors.
} 
is their financial aid history. ${ }^{2}$ If this hypothesis is true, the detailed information about both the amount and composition of financial aid awarded to these students, as well as other specific information such as SAT scores, grade point averages, and social affiliations is immensely valuable.

Finally, college and university alumni seldom make large donations during their first eight years after graduation. Indeed, the largest average annual gift for those who donated to Vanderbilt during the first eight years after they graduated is only $\$ 4,100$; the average annual gift is but $\$ 32$. However, alumni fund-raisers seem to believe that contribution patterns are developed early in life and there is some evidence that past giving is related to current giving (Lindahl and Winship, 1992; OKunade and Justice, 1991). The relatively few individuals who make large donations to their alma mater after they reach the pinnacle of their careers are most likely to have established a pattern of giving earlier in life. Therefore, to the extent that loan repayments discourage individuals from making regular contributions in the years immediately following graduation, need-based loans may reduce the pool from which larger donations might develop subsequently. Thus, the net present value of any effect of loan obligations on either the propensity to contribute or the amount of contributions made by individuals during the eight years immediately following graduation may be much larger than is evident from our empirical estimates.

\section{Model and Estimation Technique}

The two outcomes in which we are interested are the decision to donate and the amount donated. First, the individual decides whether or not a gift is going to be made. We model the decision to give with the following index function:

$$
d=X \beta+\mu
$$

where a donation is given whenever $d$ is greater than zero. We assume that the error term is normally distributed and estimate the implied probit model.

Second, the magnitude of the donation is modeled as a linear function of observables, i.e.

$$
y^{*}=Z \gamma+\varepsilon
$$

\footnotetext{
${ }^{2}$ Alternative models of the motivation for giving include pure altruism, avoidance of social stigma, tax incentives, recognition for generosity, a response to past or deterrence to future solicitation, and quid pro quo for services rendered indirectly such as access to elite social circles or business contacts.
} 
where $Z$ may contain, but is not restricted to, the variables in $X$. Furthermore, there are no cross equation restrictions between $\beta$ and $\gamma$, even for coefficients on the same explanatory variable. For example, the effect of receipt of financial aid on the likelihood of giving is allowed to differ from its effect on the expected magnitude of the gift. Finally, we do not observe $y^{*}$ for all respondents. Instead we observe

$$
\begin{array}{ll}
y=y^{*} & \text { if } d>0 \\
y=0 & \text { if } d \leq 0
\end{array}
$$

i.e. we observe the gift size for the sub-population of individuals who desire to make a positive donation, but observe a gift size of zero for all others. In general, the selection imposed by the first stage is correlated with the error term in the second stage, resulting in an omitted variables problem if OLS estimates are computed ignoring the selection. In particular, if $\varepsilon$ has a normal distribution, then

$$
E\left\{y^{*} \mid d>0\right\}=Z \gamma+E\{\varepsilon \mid d>0\}=Z \gamma+\rho \sigma_{\varepsilon} \lambda(X \beta)
$$

where $\rho$ is the correlation between $\varepsilon$ and $\mu, \sigma_{\varepsilon}$ is the standard deviation of $\varepsilon$, and $\lambda(X \beta)$ is the inverse Mills ratio. Therefore, we compute the inverse Mills ratio based on the estimates in the first stage and include this estimate of the inverse Mills ratio as an additional regressor in the second stage. This procedure was introduced in Heckman (1979) and has been shown to produce consistent estimates. Finally, standard errors are corrected both for the heteroscedasticity induced by selection and the fact that the inverse Mills ratio is an estimated regressor.

\section{Data}

The data consist of 2,822 full-time students who entered Vanderbilt University as freshmen between August 1984 and August 1986 and graduated between May 1988 and May 1990. ${ }^{3}$ No transfer students (either into or out of Vanderbilt) are in the sample. Contributions from each graduate in our sample pertain to the first eight years after graduation. The eight years of postgraduate experience for which we do have information allow sufficient time for individuals to complete most post-graduate professional programs, even allowing for a few years of preprofessional program work experience. These data are used to examine both the probability of making a donation and the expected magnitude of donations.

\footnotetext{
${ }^{3}$ Data are unavailable for earlier cohorts.
} 
Vanderbilt's alumni and development office provided the date, amount, form (cash, stock, or in-kind), and destination unit of every gift made by individuals in our sample during the first eight years after graduation. Gifts matched by corporate employers are also identified. Contributions designated for undergraduate academic units, athletics, reunion events, libraries, and undesignated contributions are accumulated to form our dependent variable in the regression analysis, which we identify as gifts to the undergraduate college. Gifts designated for schools without undergraduate programs or for the university hospital are not included. A binary variable indicating if a gift was made to the undergraduate college is the dependent variable in the likelihood of giving probit model. The average annual contribution amount over the eight year period is the dependent variable in the second equation.

The explanatory variables are separated into five categories: financial aid, sociodemographic, college experience, post-college experience, and charitable behavior. Descriptive statistics and results of a two-tailed test for a difference in the means between donors and nondonors for each of these variables are reported in table 1. Our expectations regarding the relationship of each variable to both the probability of contributing and the expected size of the contribution are described below. However, for each dependent variable these expectations are the same, e.g., if we expect a variable to increase the likelihood of giving, then we expect it to increase the average gift size as well. Therefore, no distinction between the two outcomes is made in the following discussion and they are often referred to as charitable behavior. The predicted signs of these relationships are reported in table 2, along with the empirical estimates.

Before describing any particular variable in detail, a few general points will expedite the presentation. First, most of the variables are binary variables; only exceptions will be noted explicitly. Second, two key variables, earnings and wealth, are not available. Hence, the empirical analysis does not control directly for these factors, potentially biasing the estimated coefficients in the analysis. ${ }^{4}$ Most importantly, the need-based financial aid variables are necessarily correlated with family wealth. Due to this fact, we emphasize the probability of giving equation, as opposed to the expected magnitude of a gift equation, since we believe earnings and wealth have a smaller impact on the propensity to give than the quantity given. Third, all dollar valued variables are measured in thousands of constant 1997 dollars.

\footnotetext{
${ }^{4}$ Student major and grade point average may control for income indirectly.
} 


\subsection{Financial Aid Variables}

Every form of financial aid considered below eases the budget constraint of the student and her family. Additionally, the award may bestow psychological benefits on the recipient. To the degree that either of these attributes is appreciated by recipients, we expect it to induce more generous charitable behavior. Thus, we expect non-need-based aid to increase both the likelihood of giving and the average gift size. However, since our data prevent us from controlling for earnings and wealth and need-based aid is negatively correlated with these omitted variables, we are unable to make unambiguous predictions about the direction of the effect of need-based aid on alumni contributions.

Need-based loans. Need-based loans include both institutionally funded loans and federal loans (Stafford and Perkins) that are administered through the university. Repayment usually commences six to nine months after graduation and extends over a ten year period. Thus, repayments for the typical graduate are due throughout our sample period.

Need-based scholarships. Need-based scholarships are institutionally funded need-based grants that do not require repayment. Pell Grants are not included because they are recognized as entitlements that are independent of the college or university the student chooses to attend, so do not affect the student's attitude about Vanderbilt. These are likely to be highly negatively correlated with the income and wealth of graduates' families.

Total need-based financial aid. Total need-based financial aid is a continuous variable that measures the sum of Pell Grants, need-based scholarships and need-based loans received by a student. It excludes College Work Study Program (CWSP) awards. Although most student aid packages at Vanderbilt include a CWSP award, the data do not permit us to determine if a student chose to take it up. ${ }^{5}$

Percentage of aid received as loans. Holding constant the total amount of need-based financial aid, an increase in the proportion that consists of loans indicates a less generous financial aid package from the university and a greater loan repayment burden. Consequently, we expect it to be associated with less charitable giving to the university.

\footnotetext{
${ }^{5}$ Only about 75 percent of CWSP dollars offered are actually claimed. However, the CWSP offer is approximately the same fraction of most student financial aid packages, so its omission is unlikely to bias the estimated coefficients.
} 
Merit scholarships. Merit scholarships are non-need-based grants to students awarded for academic or extracurricular achievements in high school. We expect more contributions from former merit scholarship holders for two reasons. First, the honor of receiving a merit scholarship enhanced their undergraduate experience. Second, former merit scholarship holders are more likely to be high achievers and consequently high earners.

Amount of merit scholarship. The amount of merit scholarship is a continuous variable representing the dollar value of merit scholarship received by a student. Larger merit scholarships bring increased recognition to a student and also more relief on other financial responsibilities. This should increase charitable giving.

Athletic scholarships. Athletic scholarships are need-blind grants. They are allocated through a recruitment process that increases self-esteem. For this reason and others similar to those identified for merit scholarships we expect positive coefficients for this variable.

\subsection{Socio-Demographic Variables}

White. 95 percent of Vanderbilt graduates in the sample are white. Therefore, we make no attempt to differentiate between minority groups due to a lack of sample size.

Female. Eckel and Grossman (1998) found that women are more inclined to make charitable contributions in larger amounts. However, on average, men earn more than women, providing access to more resources to support donations. Consistent with greater ability to pay, Okunade (1996) found that male graduates of the University of Memphis contributed more than female graduates. Clotfelter (2000) finds no significant difference in contributions between men and women who were enrolled in 14 selective private colleges and universities in 1976. Our inability to control for earnings makes the direction of the effect of this variable an empirical question.

Private high school. Students who attended private high schools are likely to come from families with greater financial resources, which may affect the size of donations to their alma mater after graduation. On the other hand, competition from private high school solicitations may lure contributions away from Vanderbilt. Thus the expected effect of this variable is ambiguous.

\subsection{College Experience Variables}

A student's college experience is a function of both her social interactions and her academic success. The more favorable an experience a student has, the more likely she is to reward the 
university with charitable gifts. The variables identified below are intended as proxies for these two attributes of a student's undergraduate experience.

Greek affiliation. Harrison, Mitchell, and Peterson (1995) found higher alumni giving at institutions with a higher percentage of students who pledged fraternities and sororities. The usual interpretation of such results is that students who participate in the extensive social and community activities arranged by Greek organizations feel a stronger sense of attachment to the university. Furthermore, membership in a fraternity or sorority requires substantial dues, which tends to bias Greek membership toward students from relatively wealthier families, possibly increasing subsequent contributions. On the other hand, OKunade and Justice (1991) found that alumni who were members of social Greek organizations donated significantly less tot he university of Memphis for academic purposes. They hypothesized that this finding reflected the competition between Greek organizations and academic units for the support of their common alumni. Membership in fraternities and sororities is identified by separate variables.

Athletes. This variable includes only varsity athletes. As with Greek affiliation, participation on a varsity athletic team generates a stronger sense of attachment to the university through group membership. In addition, former athletes receive solicitations from a special club of former athletes in addition to the usual appeal for alumni contributions. Thus, we expect former athletes to contribute more than other graduates.

Cumulative grade point average (GPA). Higher GPAs may lead both to more satisfied students and to higher earnings (Jones and Jackson, 1990), both of which should increase charitable behavior.

Grade point differential. This variable measures each graduate's cumulative grade point average at Vanderbilt less his or her (standardized) grade point average in core subjects taken in high school. We expect higher values of the GPA differential to reflect greater satisfaction with a graduate's academic performance at college and, consequently, to increase charitable giving.

Number of semesters to earn degree. Seven percent of the sample took longer than eight semesters to graduate. ${ }^{6}$ We hypothesize that students who did not graduate "with their class" are likely to have had a less satisfying undergraduate experience and have had to pay for additional

\footnotetext{
${ }^{6}$ The sampling frame causes this estimate to understate the percentage of students exceeding eight semesters to graduation. For example, no freshmen from 1986 who took more than eight semesters are included in the sampling frame.
} 
semesters in attaining their degree. We believe both of these factors induce them to contribute less.

Leave of absence. This variable indicates a student took a formal leave of absence during the undergraduate years. Students take leaves of absence for various reasons, including illness, poor grades, honor code violations, and financial problems. The majority of the potential reasons are likely to reduce a graduate's satisfaction with his or her undergraduate experience. Thus we expect negative coefficients on this variable.

Undergraduate major. A series of binary variables are included to distinguish nine groups of majors. They are listed in tables 1 and 2 . Humanities is the omitted category. ${ }^{7}$ Students majoring in two areas are included in both; thus these variables sum to more than one. We expect differences across majors since disciplines attract different types of students and provide distinct earnings potentials. For example, a stereotype of an education major is a relatively more patient and generous person, who therefore might be more likely to donate, although in modest amounts because of low expected net earnings. The academic area variables may also capture the extent to which there is a systematic difference in student satisfaction across departments or divisions of the university. For example, the positive (albeit insignificant) coefficient associating economics majors with a greater likelihood of giving might be interpreted in a self-serving way by these authors as reflecting the superior undergraduate experience received by economics students at Vanderbilt! Alternatively, it might reflect higher earnings of economics graduates (OKunade and Justice, 1991). Finally, academic majors reflect likely differences in earnings in the years immediately after graduation. For example, engineers enjoy the highest average earnings in the first decade after graduation (Hecker, 1993) and thus have greater capacity to contribute. However, we take no stand on the expected sign of any major.

\subsection{Post-College Environment Variables}

Marital status, graduate school and children all affect the budget constraint of graduates. Therefore, we expect them to affect graduates' charitable giving. However, unless otherwise stated, we have no strong prior convictions of the direction of the impact of any of the variables below. Furthermore, if earnings and wealth were available, their inclusion would undoubtedly change the estimated effect of these variables.

\footnotetext{
${ }^{7}$ Human and organizational development is a quasi-business major focused away from finance and accounting.
} 
Marital status. Marital status is based on the graduate's most current status available in the sampling period; the expected sign of the coefficient is ambiguous. On the one hand, single alumni may maintain stronger allegiance to their alma mater than married alumni because married alumni have moved on to another stage of their lives. Thus single alumni would be more inclined to give. On the other hand, married alumni may be more inclined to make contributions to their alma mater in order to appear generous to their spouses. If both husband and wife work and there are some scale economies of living together, a married couple also would have more disposable income available from which to contribute.

Married to alumni. We are able to determine if graduates are married to other Vanderbilt alumni. We expect these graduates to have more affection for their undergraduate experience at Vanderbilt (assuming a happy marriage). Furthermore, the average return to giving may be greater for these graduates because each receives the additional indirect benefit of improving their spouse's university. For these reasons, we expect greater charitable giving from this group.

Number of children. A simple count records the number of children an alumnus has where the default is zero when the alumni office has no information. Alumni with higher income tend to have more children. Furthermore, parents are relatively more interested in the quality of education at all levels than are non-parents. However, children add financial responsibilities and constrain income available for charitable contributions. The expected sign is therefore ambiguous.

Nashville resident. Nashville residents are more likely to enjoy external benefits from a successful local university. Furthermore, the residential decision of alumni who remain in Nashville indicates that they did not experience the need to "get out of this place" that afflicts many undergraduate students as they approach graduation. These factors lead us to expect Nashville residents who graduated from Vanderbilt to be more charitable towards the university.

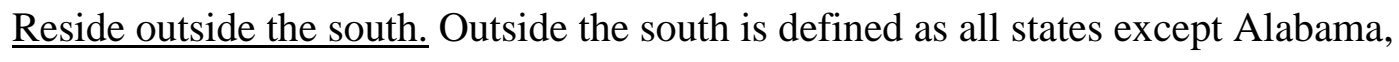
Arkansas, Georgia, Kentucky, Louisiana, Mississippi, North Carolina, South Carolina, Tennessee, Texas, Virginia, and West Virginia. The converse of the reasoning for Nashville residents leads us to expect these individuals to be less generous to the university as alumni.

Graduate school. Thirty six percent of the sample are known to have earned a graduate or professional degree. A quarter of those degrees are from Vanderbilt and are identified separately 
in the analysis. These individuals are likely to have higher expected earnings, but their graduate institution is an additional competitor for contributions. Thus, the expected signs on these variables are ambiguous.

\subsection{Charitable Behavior}

Contributions to other units of Vanderbilt University. Both the frequency and the magnitude of donations to other units of Vanderbilt can be interpreted as a general reflection of individuals' generosity. As such, we would expect a positive impact for both the binary and continuous variables relating giving to other units of the university to charitable behavior of alumni towards the undergraduate school. However, graduate and professional schools and the university hospital also can be viewed as competitors for donations, in which case one would expect negative effects.

Corporate matching programs. A corporate matching program reduces the effective price of a contribution and should lead to an increase in charitable behavior. Unfortunately, we have information about employers' matching policies only for graduates who made contributions. Consequently the corporate matching variable is included only in the average gift size equation (this is the only difference in explanatory variables between the two estimated equations). Furthermore, we know only whether donations were matched by a graduate's employer, not the rate at which they are matched. Therefore, we define this variable as the dollar value of the graduates' donations that are matched divided by the dollar value of all the graduate's donations.

We expect a substantial positive elasticity with respect to the match rate, but even if this expectation is correct we cannot guarantee a positive coefficient on this variable. The dependent variable in the analysis is the amount of dollars spent on contributions to Vanderbilt, not the quantity of dollars received by Vanderbilt. All that economic theory predicts is that when the price of a good falls (the cost of sending a dollar to Vanderbilt), the quantity purchased will rise. It does not require individuals to increase the amount they spend on that good. For example, suppose a typical contributing graduate who would give $\$ 32$ with no corporate match receives a 100 percent corporate match. Economic theory predicts that the graduate will give in excess of $\$ 16$, ensuring that Vanderbilt receives in excess of $\$ 32$. Furthermore, if this graduate's elasticity was 0.5 , then we would observe a gift of $\$ 24$ resulting in a net receipt of $\$ 48$ for Vanderbilt. However, this scenario would produce a coefficient of negative $\$ 8$ on the match variable in the 
equation determining average gift size. In order to have a positive coefficient on this variable, it is necessary and sufficient for the elasticity to be in excess of one.

\section{Empirical Results}

Table 2 contains the estimates of each explanatory variable's effect on the likelihood of making at least one contribution during the eight years after graduation and on the expected size of such contributions. We consider the estimates for the expected gift size (the second equation) first.

\subsection{Expected Gift Size}

Given that the average gift size is $\$ 32$, it is not surprising that the estimated coefficients are generally small in magnitude and rarely statistically significant. There are four exceptions to this pattern. First, receipt of an academic honor scholarship increases the average gift size by $\$ 181 .^{8}$ However, this impact is partially offset by the (surprising) negative coefficient on the size of the merit award. ${ }^{9}$ Of course, the two coefficients must be interpreted together. In particular, at the average size merit award of $\$ 5,879$ the net effect of a merit award remains positive, but falls to $\$ 49$. Merit awards exceeding $\$ 8,083$ (still within one standard deviation of the mean) have a net negative effect on average contribution size. In other words, the long run net cost of small merit awards appears to be less than their nominal value, while the opposite is true of larger, "full-ride" awards. This surprising result suggests that a strategy of more numerous but lower valued merit awards may increase future fundraising relative to fewer, but better funded merit awards.

Second, cumulative GPA has a negative impact of $\$ 30$ per grade point on average gift size. This effect is largely offset by the $\$ 28$ increase in the average contribution associated with a grade point increase in GPA relative to high school GPA, however.

Third, as expected on the basis of likely externalities, those residing outside of the south make smaller average contributions.

Fourth, there is strong evidence that contribution size is inversely related to price. Contributions that were subject to a corporate match were statistically significantly larger than other gifts (a $t$-value above seven). The point estimate of the added contribution caused by a

\footnotetext{
${ }^{8}$ Receipt of an athletic scholarship increases the average gift size by $\$ 41$.

${ }^{9}$ Students with the ability to attract a large merit award for their undergraduate education are more likely to pursue post-graduate education, and consequently are less likely to make contributions during their years as young alumni (OKunade, Wunnava and Walsh, 1994). However, we control for enrollment in graduate or professional school. Thus, the result is "surprising."
} 
corporate match is $\$ 1.60$, or five percent of the average gift size of contributors. Therefore, we can conclude that the elasticity of contributions with respect to the match rate is in excess of one. If the average match rate is 100 percent, then the elasticity is approximately $1.1 .^{10}$

Our results provide no evidence that receipt of need-based aid nor the amount of that aid affects the size of contributors' gifts. On the other hand, Baade and Sundberg (1996) found that students receiving financial aid at two out of three institutions they studied made significantly smaller contributions as alumni.

\subsection{Likelihood of Giving}

Unlike the expected gift size, the estimated impact of most of the variables on the probability of making a donation is economically substantial and frequently statistically significant. The variables are discussed in the same groups in which they were presented: financial aid, sociodemographic, college experience, post college experience and charitable behavior.

\subsubsection{Financial Aid}

In short, the types of financial aid received appear to be much more important than the quantity given. Receipt of a need-based loan lowers the probability of giving by 13 percent. Receiving a need-based scholarship, however, raises this probability by 12 percent. Given that 80 percent of the students with any need-based aid receive both loans and scholarships in their aid package, these two effects generally offset each other. Of greater interest is that neither the total amount of need-based aid nor the decomposition of that aid between loans and scholarship impacts the probability of giving. In other words, whether or not a student receives a scholarship or a loan, not the size of these awards, is what affects alumni donations. ${ }^{11}$

\subsubsection{Socio-Demographics}

Unlike Eckel and Grossman (1998), we find no differences in generosity between men and women. On the other hand, graduates who attended a private high school are about ten percent more likely to contribute.

\footnotetext{
${ }^{10}$ The elasticity of contributions with respect to the match rate is the increase in the average post match gift size divided by the average gift size or $\{(32.50+1.60)(1+$ match $)-32.50\} / 32.50=\{(34.10)(2)-32.50\} / 32.50 \approx 1.1$.

${ }^{11}$ This last conclusion is supported by the results pertaining to merit scholarships. Although the point estimates are not statistically significant, the receipt of the scholarship increases the probability of donating by about 7 percent, but the amount of the merit scholarship has no perceptible effect.
} 


\subsubsection{College Experience}

The college experience variables have the most consistent substantial effects on the likelihood of giving. In particular, consistent with Harrison, Mitchell, and Peterson (1995), we find that students who were members of non-academic groups--fraternities, sororities and athletic teams-respond more favorably to requests for donations after graduation. The estimated effects are seven, eleven and seven percent, respectively, and all are statistically significant.

Also, students who enjoyed academic success are more likely to contribute as alumni. On the upside, a one standard deviation increase in GPA (about 0.44) raises the likelihood of giving by two percent. On the downside, students who took more than eight semesters to graduate are about eight percent less likely to donate.

Two majors, mathematics/engineering and science, have the greatest and only statistically significant effects on the likelihood of contributing, but all of the point estimates are substantial. Education, human/organizational development, performing arts, and science lower the probability of giving by two, four, five and eleven percent, respectively (humanities is the benchmark). Economics, mathematics/engineering, psychology and social science raise the probability by four, seven, two and three percent, respectively. We hypothesized that science majors would earn higher incomes than humanities majors. This increase in earnings would tend to make them more rather than less likely to donate than humanities majors. Perhaps these students, many of whom have gone on to medical school, are not yet in a financial position that reflects the net present value of their expected lifetime income stream.

\subsubsection{Post-College Experience}

Married graduates are about four percent more likely to contribute and this number increases to about six percent if their spouse is also a Vanderbilt alumnus. Although not statistically significant, this result is in accordance with Hueston (1992), which found increased donations from graduates' married to fellow alumni of New Mexico State. Graduates with children are about five percent more likely per child to contribute.

Graduates who reside in Nashville are four percent more likely to contribute. Although this coefficient is not statistically significant, it also accords with Hueston's (1992) finding that New Mexico State alumni living in Las Cruces were about the most likely donors. Also, there 
appears to be no distinction between Vanderbilt graduates who live outside the southeast and those who live in the southeast, but outside of Nashville.

Finally, in contrast to the findings of Okanade, Wunnava and Walsh (1994) alumni who remained at Vanderbilt for professional or graduate school are eight percent less likely to give to the undergraduate college, while those who attended professional or graduate schools elsewhere are about nine percent more likely to contribute. Apparently the loyalties of students who continue their education at Vanderbilt get transferred to their graduate or professional school, while those who continue their education elsewhere do not. This discovery could have implications for admissions criteria used by Vanderbilt's graduate and professional schools.

\subsubsection{Charitable Behavior}

Graduates who made donations to the university hospital or to units of Vanderbilt unconnected to undergraduate education are much more likely to contribute to the undergraduate college. Indeed, those who made gifts to other units are 35 percent more likely to contribute to the undergraduate college as alumni. This coefficient is statistically significant at the one percent level.

\section{Conclusion}

Financial aid is used as a strategic tool by colleges and universities to help achieve a variety of goals--strengthen the academic quality of the student body, insure a diverse student population, provide opportunities for intergenerational mobility in income and wealth, and strengthen the financial condition of the institution. Although much has been written about the implications of various financial aid strategies for the short-run financial status of colleges and universities, there is also the possibility that financial aid decisions made today carry implications for future voluntary contributions by alumni, and therefore the financial condition of institutions of higher education in the long run.

The empirical results of this exploratory analysis suggest that discrete changes in the packaging of financial aid eventually may affect the willingness of alumni to contribute. It appears that small loans in mixed grant/loan packages may have negative long run financial implications. Adding a modest grant to an otherwise exclusive loan package could have a positive net present value to an institution by increasing the likelihood of receiving future contributions from the aid recipient. 
Finally, it is clear that students' willingness to contribute to their alma mater is affected by their undergraduate experiences. Decisions regarding Greek organizations, athletics, grading policies, and efforts to keep students "on track" to graduate with their entering class all bear, to one degree or another, on the likelihood that students will continue to support their college or university after they graduate. 


\section{References}

Baade, Robert A. and Jefferey O. Sundberg, "Identifying the Factors that Stimulate Alumni Giving" Chronicle of Higher Education Volume 40, Issue 6 (September 29, 1993): B1 B2.

Baade, Robert A. and Jefferey O. Sundberg, "What Determines Alumni Generosity?" Economics of Education Review Volume 15, Issue 1 (February, 1996): 75 - 81.

Chronicle of Higher Education, Almanac (September, 1999)

Clotfelter, Charles T., "Alumni Giving to Elite Private Colleges and Universities," unpublished manuscript (Durham, N.C.: Duke University, April 2000).

Eckel, Catherine, and Philip Grossman, "Are Women Less Selfish than Men?: Evidence from Dictator Experiments," The Economic Journal Volume 108, Issue 448 (May 1998): - .

Harrison, William B., Shannon K. Mitchell, and Steven P. Peterson,"Alumni Donations and Colleges' Development Expenditures: Does Spending Matter?" The American Journal of Economics and Sociology XX (October 1995), pp. 397 - 413.

Hecker, Daniel E., "Earnings of College Graduates, 1993," Monthly Labor Review 118 (December, 1995), pp. 3 - .

Heckman, James, "Sample Selection Bias as a Specification Error," Econometrica Volume 47, Issue 1 (January, 1979): 153 - 161.

Hueston, Frederick R., "Predicting Alumni Giving: A Donor Analysis Test," Fund Raising Management XX (July 1992), pp. 18-23.

Jones, Ethel B. and John D. Jackson, "College Grade and Labor Market Rewards," Journal of Human Resources Volume 25, Issue 2 (Spring, 1990): 253 - 266.

Leslie, Larry L. and Garey Ramey, "Donor Behavior and Voluntary Support for Higher Education Institutions," Journal of Higher Education Volume 59, Issue 2 (April, 1988): $115-132$.

Lindahl, Wesley E. and Christopher Winship, "Predictive Models for Annual Fundraising and Major Gift Fundraising," Nonprofit Management and Leadership Volume 3 (Fall, 1992): $43-64$.

McPherson, Michael S., and Morton Owen Schapiro, The Student Aid Game: Meeting Need and Rewarding Talent in American Higher Education (Princeton, N.J.: Princeton University Press, 1998).

Mulugetta, Yuko, Scott Nash and Susan H. Murphy, "What Makes a Difference: Evaluating the Cornell Tradition Program," in Joseph Pettit and Larry H Litlen edition, A New Era of Alumni Research: Improving Institutional Performance and Better Serving Alumni (San Francisco: Jossey-Bass Publishers, 1999): 61 - 80.

OKunade, Albert Ade, "Graduate School Alumni Donations to Academic Funds: Micro-data Evidence," American Journal of Economics and Sociology Volume 55 (April, 1996): 213 - . 
OKunade, Albert Ade and Scott Justice, "Micropanel Estimates of the Life-Cycle Hypothesis with Respect to Alumni Donations," 1990 Proceedings of the Business and Economic Statistics Section of the American Statistical Association (Alexandria, VA: American Statistical Association 1991): 298 - 305.

OKunade, Albert Ade, Phanindra V. Wannava and Raymond Walsh, Jr.. "Charitable Giving of Alumni: Micro-data Evidence from a Large Public University," American Journal of Economics and Sociology Volume 53 (January, 1994): 73 - 84.

Stuttler, Doug and Dave Calvario, "In Alumni Support, Satisfaction Matters," Fund Raising 27 (November, 1996): 12 - 13. 
Table 1: Descriptive Statistics

\begin{tabular}{|c|c|c|c|c|c|c|}
\hline $\begin{array}{l}\text { Explanatory } \\
\text { Variable }\end{array}$ & Min & Max & Mean & $\begin{array}{c}\text { Standard } \\
\text { Deviation }\end{array}$ & $\begin{array}{r}\mathrm{Me} \\
\text { Donors }\end{array}$ & $\begin{array}{l}\text { Non-Donors } \\
\text { Non }\end{array}$ \\
\hline \multicolumn{7}{|l|}{ Financial Aid } \\
\hline Need-Based Loan & 0 & 1 & 0.19 & 0.39 & 0.17 & $0.22 * *$ \\
\hline Need-Based Scholarship & 0 & 1 & 0.18 & 0.38 & 0.17 & $0.19 *$ \\
\hline Total Need-Based Aid & 0 & 14.24 & 1.32 & 2.89 & 1.17 & $1.50 * *$ \\
\hline Percent of Total Aid in Loans & 0 & 100 & 8.94 & 21.14 & 7.68 & $10.44 * *$ \\
\hline Merit Scholarship & 0 & 1.00 & 0.05 & 0.21 & 0.05 & $0.03 * *$ \\
\hline Amount of Merit Scholarship & 0 & 15.64 & 0.26 & 1.43 & 0.33 & $0.19 * *$ \\
\hline Athletic Scholarship & 0 & 1 & 0.04 & 0.19 & 0.03 & 0.04 \\
\hline
\end{tabular}

Socio-Demographic

White$$
0
$$

Female

0

Private High School

$\begin{array}{llll}0 & 1 & 0.43 & 0.50\end{array}$

0.95

$0.94 * *$

College Experience

Fraternity (Men)

$\begin{array}{llllll}0 & 1 & 0.27 & 0.44 & 0.28 & 0.25 * \\ 0 & 1 & 0.31 & 0.46 & 0.34 & 0.27 * * \\ 0 & 1 & 0.09 & 0.29 & 0.10 & 0.08\end{array}$

Sorority (Women)

Athlete

$4.00 \quad 2.95$

0.44

2.98

$2.92 * *$

GPA minus HS GPA

$1.78 \quad-0.38$

0.49

$-0.36$

$-0.40 * *$

More than 8 Semesters

$\begin{array}{lll}0 & 1 & 0.07\end{array}$

0.26

0.06

$0.09^{* *}$

Leave of Absence

0

0.23

0.05

$0.07 *$

Major

$\begin{array}{lllllll}\text { Economics } & 0 & 1 & 0.15 & 0.36 & 0.17 & 0.14 * * \\ \text { Education } & 0 & 1 & 0.06 & 0.24 & 0.06 & 0.06 \\ \text { Human/Org. Development } & 0 & 1 & 0.06 & 0.25 & 0.06 & 0.07 \\ \text { Mathematics/Engineering } & 0 & 1 & 0.28 & 0.45 & 0.30 & 0.25 * *\end{array}$


Table 1: Descriptive Statistics

\begin{tabular}{|c|c|c|c|c|c|c|}
\hline $\begin{array}{l}\text { Explanatory } \\
\text { Variable } \\
\end{array}$ & Min & Max & Mean & $\begin{array}{r}\text { Standard } \\
\text { Deviation }\end{array}$ & $\begin{array}{r}\mathrm{M} \\
\text { Donors }\end{array}$ & $\begin{array}{l}\text { ean } \\
\text { Non-Donors }\end{array}$ \\
\hline Performing Arts & 0 & 1 & 0.01 & 0.08 & 0.01 & 0.01 \\
\hline Psychology & 0 & 1 & 0.09 & 0.29 & 0.09 & 0.09 \\
\hline Science & 0 & 1 & 0.08 & 0.27 & 0.06 & $0.10 * *$ \\
\hline Social Science & 0 & 1 & 0.17 & 0.38 & 0.18 & 0.16 \\
\hline \multicolumn{7}{|l|}{ Post-College Environment } \\
\hline Married & 0 & 1 & 0.54 & 0.50 & 0.59 & $0.48 * *$ \\
\hline Married to Alumni & 0 & 1 & 0.19 & 0.39 & 0.22 & $0.16 * *$ \\
\hline Number of Children & 0 & 4 & 0.28 & 0.64 & 0.34 & $0.21 * *$ \\
\hline Nashville Resident & 0 & 1 & 0.08 & 0.27 & 0.08 & 0.07 \\
\hline Reside Outside the South & 0 & 1 & 0.44 & 0.50 & 0.42 & 0.45 \\
\hline Vanderbilt Grad./Prof. School & 0 & 1 & 0.09 & 0.29 & 0.10 & 0.08 \\
\hline Other Grad./Prof. School & 0 & 1 & 0.27 & 0.44 & 0.31 & $0.22 * *$ \\
\hline \multicolumn{7}{|l|}{ Charitable Behavior } \\
\hline Donate Elsewhere & 0 & 1 & 0.06 & 0.23 & 0.00 & 0.00 \\
\hline Amount Donated Elsewhere & 0 & 12.50 & 0.02 & 0.26 & 0.03 & $0.01 * *$ \\
\hline$\%$ of Giving Matched & 0 & 100 & & & 5.28 & \\
\hline
\end{tabular}


Table 2: Empirical Estimates

( $t$-statistics in parentheses)

\begin{tabular}{lr|rr|r}
\hline \hline & Expected & \multicolumn{2}{|c|}{ Probit Estimates } & Regression Estimates \\
Variable & Sign & Coefficient & Marginal Effect & Coefficient \\
\hline Intercept & \multicolumn{3}{c}{-0.72}
\end{tabular}

Financial Aid

Need-Based Loan

$?$

$-0.36$

$-0.132$

20.27

$(-1.27)$

Need-Based Scholarship

$?$

$0.32 *$

0.117

$-45.44$

(1.82)

$(-0.83)$

Total Need-Based Aid

?

$-0.01$

$-0.004$

2.32

$(-0.45)$

Percent of Total Aid in Loans

$\begin{array}{rr}-\quad & 0.00 \\ & (0.05)\end{array}$

0.000

$-0.12$

(0.05)

$(-0.22)$

Merit Scholarship

$+\quad 0.20$

0.071

$181.15 * *$

(0.83)

Amount of Merit Scholarship

$+\quad 0.01$

0.003

$-22.41 * *$

$(0.21)$

$(-4.23)$

Athletic Scholarship

-0.15
$-\quad(-0.91)$

$-0.056$

41.23

Socio-Demographic

White

$?$

$$
0.06
$$

0.023

$-25.10$

(0.55)

Female

$?$

$-0.01$

$-0.004$

0.50

$(-0.13)$

Private High School

$?$

$0.10 *$

0.038

$-4.70$

(1.91)

$(-0.26)$

College Experience

Fraternity (Men)
$+\quad 0.19 * *$
(2.66)

0.069

$-2.44$

Sorority (Women)

$0.31 * *$
$(4.26)$

0.113

$-0.19$

$(-0.00)$ 
Table 2: Empirical Estimates

( $t$-statistics in parentheses)

\begin{tabular}{|c|c|c|c|c|}
\hline \multirow[b]{2}{*}{ Variable } & \multirow{2}{*}{$\begin{array}{r}\text { Expected } \\
\text { Sign } \\
\end{array}$} & \multicolumn{2}{|c|}{ Probit Estimates } & \multirow{2}{*}{$\begin{array}{r}\text { Regression Estimates } \\
\text { Coefficient }\end{array}$} \\
\hline & & Coefficient 1 & Marginal Effect & \\
\hline Athlete & + & $\begin{array}{l}0.18 * * \\
(1.66)\end{array}$ & 0.066 & $\begin{array}{r}-9.16 \\
(-0.29)\end{array}$ \\
\hline Cumulative GPA & + & $\begin{array}{l}0.12 * \\
(1.55)\end{array}$ & 0.043 & $\begin{array}{l}-29.78 \\
(-1.38)\end{array}$ \\
\hline GPA minus HS GPA & + & $\begin{array}{r}-0.03 \\
(-0.38)\end{array}$ & -0.009 & $\begin{array}{l}27.78 * * \\
(2.33)\end{array}$ \\
\hline More than 8 Semesters & - & $\begin{array}{l}-0.21 * * \\
(-2.04)\end{array}$ & -0.076 & $\begin{array}{l}11.67 \\
(0.34)\end{array}$ \\
\hline Leave of Absence & - & $\begin{array}{r}-0.08 \\
(-0.70)\end{array}$ & -0.028 & $\begin{array}{l}10.67 \\
(0.49)\end{array}$ \\
\hline
\end{tabular}

Major

Economics
0.11

0.041 7.80

(1.48)

Education

$?$

$$
\begin{array}{r}
-0.06 \\
(-0.56)
\end{array}
$$

$-0.023$

$-7.27$

Human/Org. Development

$?$

$-0.12$

$-0.043$

$-15.45$

(-1.09)

Mathematics/Engineering

$?$

$0.20 * *$

0.073

$-14.71$

(2.97)

$(-0.46)$

Performing Arts

$-0.14$

$-0.053$

10.43

$(-0.45)$

(0.18)

Psychology

$?$

0.07

0.025

$-13.53$

(0.76)

$(-0.75)$

Science

$?$

$-0.31 * *$

$-0.114$

10.79

$(-3.07)$

Social Science

$?$

0.07

0.025

$-7.97$

(0.93)

$(-0.50)$

Post-College Environment 
Table 2: Empirical Estimates

( $t$-statistics in parentheses)

\begin{tabular}{|c|c|c|c|c|}
\hline \multirow[b]{2}{*}{ Variable } & \multirow{2}{*}{$\begin{array}{r}\text { Expected } \\
\text { Sign } \\
\end{array}$} & \multicolumn{2}{|c|}{ Probit Estimates } & \multirow{2}{*}{$\begin{array}{r}\text { Regression Estimates } \\
\text { Coefficient }\end{array}$} \\
\hline & & Coefficient 1 & Marginal Effect & \\
\hline Married & $?$ & $\begin{array}{l}0.10 * \\
(1.68)\end{array}$ & 0.036 & $\begin{array}{r}-4.56 \\
(-0.28)\end{array}$ \\
\hline Married to Alumni & + & $\begin{array}{r}0.07 \\
(1.05)\end{array}$ & 0.027 & $\begin{array}{r}8.48 \\
(0.53)\end{array}$ \\
\hline Number of Children & $?$ & $\begin{array}{l}0.15 * * \\
(3.44)\end{array}$ & 0.054 & $\begin{array}{r}-2.00 \\
(-0.09)\end{array}$ \\
\hline Nashville Resident & + & $\begin{array}{r}0.11 \\
(1.16)\end{array}$ & 0.042 & $\begin{array}{r}1.64 \\
(0.07)\end{array}$ \\
\hline Reside Outside the South & - & $\begin{array}{r}-0.01 \\
(-0.15)\end{array}$ & -0.003 & $\begin{array}{l}-14.74 * * \\
(-1.70)\end{array}$ \\
\hline Vanderbilt Grad./Prof. School & $?$ & $\begin{array}{l}-0.21 * * \\
(-2.06)\end{array}$ & -0.078 & $\begin{array}{r}-0.69 \\
(-0.02)\end{array}$ \\
\hline Other Grad./Prof. School & $?$ & $\begin{array}{l}0.24 * * \\
(4.17)\end{array}$ & 0.088 & $\begin{array}{l}-10.55 \\
(-0.29)\end{array}$ \\
\hline \multicolumn{5}{|l|}{ Charitable Behavior } \\
\hline Donate Elsewhere & $?$ & $\begin{array}{l}0.96 * * \\
(6.47)\end{array}$ & 0.349 & $\begin{array}{l}-45.68 \\
(-0.30)\end{array}$ \\
\hline Amount Donated Elsewhere & $?$ & $\begin{array}{r}0.10 \\
(0.55)\end{array}$ & 0.038 & $\begin{array}{l}10.20 \\
(0.41)\end{array}$ \\
\hline$\%$ of Giving Matched & $?$ & ---- & ---- & $\begin{array}{l}1.60 * * \\
(7.84)\end{array}$ \\
\hline Inverse Mills Ratio & + & ---- & ---- & $\begin{array}{l}80.26 \\
(0.37)\end{array}$ \\
\hline
\end{tabular}

* = significant difference in means at $10 \%$ level

$* *$ = significant difference in means at $5 \%$ level 